\title{
Foot-trembling behavior in Semipalmated Plover Charadrius semipalmatus reveals prey on surface of Brazilian beaches
}

\author{
César Cestari ${ }^{1,2}$ \\ ${ }^{1}$ Programa de Pós-graduação em Zoologia, Universidade Estadual Paulista - UNESP, \\ Av. 24A, 1515, Bela Vista, CEP 13506-900, Rio Claro, SP, Brazil \\ ${ }^{2}$ Corresponding author: César Cestari,e-mail: cesar_cestari@yahoo.com.br
}

CESTARI, C. Foot-trembling behavior in Semipalmated Plover Charadrius semipalmatus: reveals prey on surface of Brazilian beaches. Biota neotrop., 9(4): http://www.biotaneotropica.org.br/v9n4/en/abstract?shortcommunication+bn03409042009.

\begin{abstract}
Foot-trembling is a foraging technique normally performed by plovers and lapwings. It exposes preys, and may increase the likelihood of capture. Currently, no detailed description of this technique is available for the Semipalmated Plover Charadrius semipalmatus. This article described the foot-trembling behavior during wintering of this species in southeastern Brazilian beaches.
\end{abstract}

Keywords: foraging behavior, foot-trembling, Semipalmated Plover, shorebird, southeastern Brazil.

CESTARI, C. Tremular dos pés da batuíra-de-bando Charadrius semipalmatus: revelando presas na superfície de praias brasileiras. Biota neotrop., 9(4): http://www.biotaneotropica.org.br/v9n4/pt/abstract?shortcommunication+bn03409042009.

Resumo: O tremular dos pés é um comportamento de forrageio utilizado por batuíras e quero-queros que maximiza a exposição de presas e por conseqüência, pode aumentar o sucesso de captura. Apesar disso, nenhuma descrição detalhada desta técnica está disponível para batuíra-de-bando Charadrius semipalmatus. No presente estudo, eu descrevo o comportamento de tremular dos pés da espécie durante sua estadia temporária em praias na região sudeste do Brasil.

Palavras-chave: comportamento de forrageio, tremular dos pés, batuíra-de-bando, ave costeira, sudeste do Brasil. 


\section{Introduction}

Foot movements in small plovers and lapwings (Charadriidae) were described in the beginning of the $20^{\text {th }}$ century (Heinroth 1916) with most detailed observations concentrated among Old World bird species (Simmons 1961a, 1961b). The function of foot movements have been attributed to nest building, uncovering eggs, pre-copulatory displays and foraging (Simmons 1961a). Tapping or trembling movements involve the use of one leg at time during foraging in order to expose or incite movement in cryptic invertebrates of intertidal zones and grasslands (Sparks 1961, Piersma 1996). The advantage of this technique lies in the transfer of vibrations from the foot through the substrate to the prey (Tarburton 1989). This kind of movement may also startle insects on the surface, facilitating the capture of prey by visual-foraging birds (Piersma 1996, USFWS 1996).

Typically, plovers use foot-trembling to increase their capture success and intake rate (Piersma 1996). Foot-trembling of waders appears to occur mainly in the genus Charadrius including the Black-fronted Dotterel C. melanops (Heather 1977), New Zealand Dotterel C. obscurus (Searle 1984), Lesser Sand Plover C. mongolus (Piersma 1996), Piping Plover C. melodus (USFWS 1996), Killdeer C. vociferus (Smith 1969), Common-ringed Plover C. hiaticula, Little-ringed Plover C. dubius, Mountain Plover C. montanus, and Semipalmated Plover C. semipalmatus (O'Brien et al. 2006). Foottrembling has also been recorded in Black-fronted Plover Elseyiornis melanops (Taylor 2004) and Gray Plover Pluvialis squatarola (Piersma 1996), Masked Lapwing Vanellus miles (Keeley 2001) and Snowy Egret Egretta thula (Haverschmidt 1948).

The Semipalmated Plover Charadrius semipalmatus (Bonaparte 1825) migrates from the northern hemisphere from July through November to winter along coastal areas in southern United States, the Caribbean, Central America and south in South America to Brazil (Sick 1997, Nol \& Blanken 1999). Adult species size and weight depends upon the sex and body conditions during migratory journeys, ranging from 17 to $19 \mathrm{~cm}$ and 28 to $69 \mathrm{~g}$, respectively (van Gils \& Wiersma 1996, Smith \& Nol 2000). The Semipalmated Plover is commonly found on Brazilian coast (Barbieri \& Mendonça 2005, Barbieri 2007, Cestari 2008a) and may spend most of the wintering period in monospecific and heterospecific flocks (Cestari, in press).

Despite the documentation of foot-trembling in Semipalmated Plover (van Gils \& Wiersma 1996, O’Brien et al. 2006), no detailed descriptions have been obtained. In this paper I described the foot-trembling behavior of the species on southeastern Brazilian beaches.

\section{Material and Methods}

Observations of foot-trembling performed by Semipalmated Plover were conducted on sandy beaches from Itanhaém town in southeastern Brazilian coast $\left(24^{\circ} 13^{\prime} \mathrm{S}\right.$ and $\left.46^{\circ} 51^{\prime} \mathrm{W}\right)$ during the non-breeding season of 2008-2009. The relief of the beaches was smooth with low incline (of $4^{\circ}$ to $6^{\circ}$ ) and an intertidal area of $87 \pm 9 \mathrm{~m}$ according to tide variation. Low tide predominates during the day and exposes a wider beach area than during night. Only about $10 \mathrm{~m}$ of the upper portions of the beach are totally dry.

In the morning (between 8:00 to 11:00 AM) of 24 November 2008 , and 24, 27, and 29 January 2009, I walked through a transect of $4.5 \mathrm{~km}$ on the median portion of the beaches looking for Semipalmated Plover. I considered any solitary individual or flock as a contact. When a flock was seen, I focused the $8 \times 30 \mathrm{~mm}$ binocular upon one individual for $10 \mathrm{~s}$ and recorded if it was performing foot-trembling. The place where the individual was observed was categorized according to the soil wetness and hardness in saturated and soft (on the low tide area and water channels along the beach) or non-saturated and hard (beyond the low tide area and water channels).

\section{Results and Discussion}

Foot-trembling was performed in 62/89 (70\%) of contacts of Semipalmated Plover. During the performance, after a brief dash, individuals would stop and hold one of the tarsi forward at an angle of approximately $45^{\circ}$ and then vibrated the foot and tarsus rapidly (Figure 1).

The pressure on the soil created by foot-trembling varied from high to low intensity and could be detected by determining the depth of footsteps. When pressed intensively, three marks from the toes and nails were seen on the sand. Immature and adult individuals used both legs, sometimes alternating them successively. Generally, individuals pecked the surface within a distance of $2-7 \mathrm{~cm}$ in front of the location where they performed the foot-trembling in order to capture prey.

During the course of my observations, one individual with a missing left foot was encountered while it was foraging and it exhibited no foot-trembling. I followed this individual for nearly 10 minutes and this observation suggests that both feet are necessary to perform foot-trembling. Individual incapacity to perform foot-trembling may reduce the successful capture of preys and the variety of food items exposed, although this was not evaluated. However, even without the left foot, this individual beaked constantly the soil searching for preys and presents no visible physiological deficiencies such as lesser body size or slowness movements.

Foot-trembling was used in 60/62 (nearly 97\%) of contacts in non-saturated soil of upper low-tide areas. In only a few cases (2/62 or nearly $3 \%$ of contacts), this behavior was performed in saturated soil with lesser vibration of the feet than in dry sandy. These results pointed out the greater efficiency and feasibility of foot-trembling upon hard surfaces than on soft surface habitats (Tarburton 1989, Taylor 2004). Tarburton (1989) has showed a higher capture success rate of Black-fronted Dotterel Charadrius melanops when it employed foot-trembling upon hard surfaces than a simple pecking.

Plovers are obligate visual foragers with great visual acuity (Piersma 1996). During the stop and run technique normally employed in forage activities, birds wait for prey to reveal themselves coming

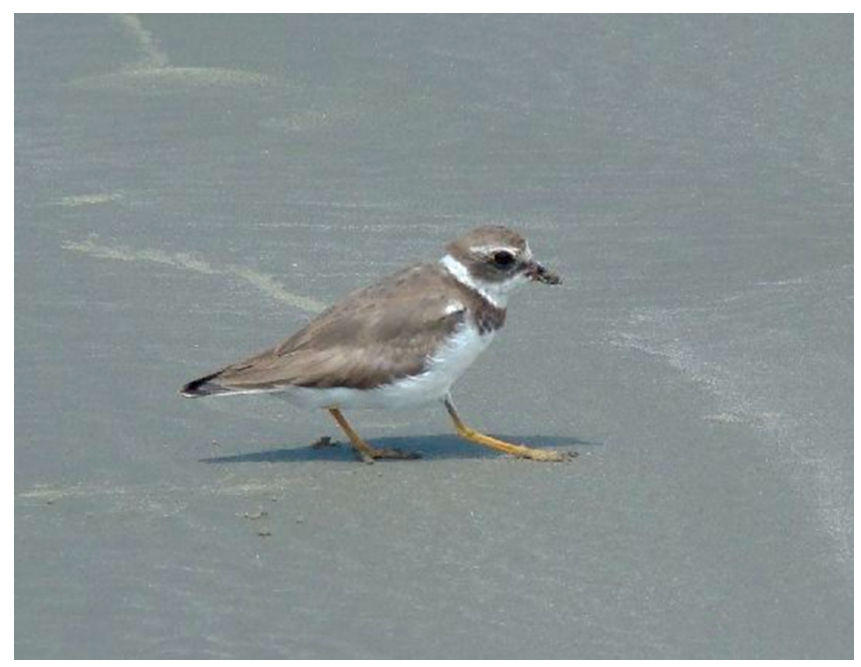

Figure 1. A Semipalmated Plover Charadrius semipalmatus performing foot-trembling behavior on southeastern Brazilian coast.

Figura 1. Uma batuíra-de-bando Charadrius semipalmatus realizando o comportamento de tremular dos pés na região sudeste da costa brasileira. 
to the surface of the ground, or if already surfaced, birds detect them by moving (Piersma 1996). In this study, I did not observe capture of invertebrates probably due to their small size and the difficulty to identify bill movements and swallowing action of the species. Studies of the diet of Semipalmated Plover found a great variety of smaller preys in their stomachs and feces (i.e., bivalve mollusks, larvae of dipterans, copepods crustaceans, amphipods, isopods) with sizes ranging of 0.5 to $5 \mathrm{~mm}$ (Baker 1977, Smith \& Nol 2000). Despite this, foot-trembling behavior may improve the exposure of prey and as consequence, prey capture success.

The Semipalmated Plover is among the few plovers whose numbers are apparently stable in North America (Morrison et al. 2006), perhaps owing to its versatility in food and habitat choice (Nol \& Blanken 1999). In Brazil, this species is one of the most abundant Nearctic shorebirds (Barbieri \& Mendonça 2005, Cestari 2008a), but studies that indicate population trends are still necessary. In a study carried out on Isthmus of Panama, Strauch Jr. \& Abele (1979) pointed out that the Semipalmated Plover appears to adapt its diet to locally abundant prey. Recently, Cestari (2008b) described a disruptive camouflage of the species, increasing its protective behavior repertoire. These considerations summed with its frequent use of foot-trembling pointed out a strong behavior plasticity that may explain the population's stability and survivorship of Semipalmated Plover in breeding and wintering territories.

\section{Acknowledgements}

I am especially indebted to Glen Mori for gently providing the English review of this manuscript; the CNPq for financial support.

\section{References}

BAKER, M.C. 1977. Shorebird food habits in the eastern Canadian Arctic. Condor 79(1):56-62.

BARBIERI, E. 2007. Seasonal abundance of shorebirds at Aracaju, Sergipe, Brazil. Wader Study Group Bull. 113(3):40-46.

BARBIERI, E. \& MENDONÇA, J.T. 2005. Distribution and abundance of Charadriidae at Ilha Comprida, São Paulo State, Brazil. J. Coast. Res. 21(2):e1-e10.

CESTARI, C. 2008a. O uso de praias arenosas com diferentes concentrações humanas por espécies de aves limícolas (Charadriidae e Scolopacidae) neárticas no sudeste do Brasil. Biota Neotrop. 8(4): http://www. biotaneotropica.org.br/v8n4/pt/abstract?article+bn01308042008 (último acesso em 26/02/2009).

CESTARI, C. 2008b. Registro de comportamento para camuflagem disruptiva de Charadrius semipalmatus (Charadriidae) em uma paisagem alterada artificialmente na região costeira do sudeste do Brasil. Atual. Ornitol. 42(2):41-43.

HAVERSCHIMDT, F. 1948. A feeding habit of the Snowy Egret. Wilson Bull. 60(3):187.
HEATHER, B.D. 1977. Foot-trembling by the black-fronted dotterel. Notornis 24(1):1-8.

HEINROTH, O. 1916. Bericht fiber die Jahresversammlung der Deutschen Ornithologischen Gesellschaft in Berlin am 17 und 18 Oktober 1915. J. Orn. 64(1):156-160.

KEELEY, B.R. 2001. Foot-trembling in Spur-Winged plover. Notornis 48(1):59-60.

MORRISON, R.I.G., MCCAFERRY, B.J., GILL, R.E., SKAGEN, S.K., JONES, S.L., PAGE, G.W., GRATTO-TREVOR, C.L. \& ANDRES, B.A 2006. Population estimates of North American shorebirds. Wader Study Group Bull. 111:67-85.

NOL, E. \& BLANKEN, M.S. 1999. Semipalmated Plover (Charadrius semipalmatus). The Birds of North America Online. 444: http://bna. birds.cornell.edu/bna/species/444doi:10.2173/bna.444 (último acesso em 19/01/09).

O’BRIEN, M., CROSSLEY, R. \& KARLSON, K. 2006. The shorebird guide. Houghton Mifflin, Boston.

PIERSMA, T. 1996. Family Charadriidae (Plovers). In Handbook of the birds of the world: Hoatzin to Auks. (J. del Hoyo, A. Elliot \& J. Sangatal, eds). Lyns Edicions, Barcelona, p. 384-443.

SEARLE, B. 1984. Foot-paddling by a New Zealand dotterel. Notornis 31(3):208.

SIMMONS, K.E.L. 1961a. Foot movements in plovers and other birds. Br. Birds 54:34-39.

SIMMONS, K.E.L. 1961b. Further observations on foot movements in plovers and other birds. Br. Birds 54:418-422.

SICK, H. 1997. Ornitologia Brasileira. Nova Fronteira, Rio de Janeiro.

SMITH, S.M. 1969. Foot trembling feeding behavior by a Killdeer. Condor $72(2): 245$.

SMITH, A.C. \& NOL, E. 2000. Winter foraging behavior and prey selection of the Semipalmated Plover on coastal Venezuela. Wilson Bull. 112(4):467-472.

SPARKS, J.H. 1961. The relationship between foot-movements and feeding in shorebirds. Br. Birds 54:337-340.

STRAUCH Jr., J.G. \& ABELE, L.G. 1979. Feeding ecology of three species of plovers wintering on the bay of Panamá, Central America. In Shorebirds in marine environments (F.A. Pitelka, ed.) Cooper Ornithological Society, Lawrense, p. 217-230. (Studies in Avian Biology, 2).

TARBURTON, M.K. 1989. Feeding behaviour of the Black-Fronted Dotterel. Notornis 36(4):249-259.

TAYLOR, I.R. 2004. Foraging ecology of the Black-fronted Plover on saline lagoons in Australia: the importance of receding water levels. Waterbirds 27(3):270-276.

USFWS. 1996. Piping Plover ( '), Atlantic Coast Population, Revised Recovery Plan. Hadley, Massachusetts.

VAN GILS, J. \& WIERSMA, P. 1996. Family Charadriidae (Plovers). In Handbook of the birds of the world: Hoatzin to Auks (J. del Hoyo, A. Elliot \& J. Sangatal, eds). Lyns Edicions, Barcelona, p. 425-426.

Received: 07/05/09

Revised: 02/12/09

Accepted: 10/12/09 